\title{
Effect of residual extractable lignin on acetone-butanol-ethanol production in SHF and SSF processes
}

Jing $\mathrm{Li}^{1}$, Yu Zhang ${ }^{3}$, Suan Shi ${ }^{2^{*}}$ and Maobing $\mathrm{Tu}^{3^{*}}$

\begin{abstract}
Background: Lignin plays an important role in biochemical conversion of biomass to biofuels. A significant amount of lignin is precipitated on the surface of pretreated substrates after organosolv pretreatment. The effect of this residual lignin on enzymatic hydrolysis has been well understood, however, their effect on subsequent ABE fermentation is still unknown.

Results: To determine the effect of residual extractable lignin on acetone-butanol-ethanol (ABE) fermentation in separate hydrolysis and fermentation (SHF) and simultaneous saccharification and fermentation (SSF) processes, we compared ABE production from ethanol-washed and unwashed substrates. The ethanol organosolv pretreated loblolly pine (OPLP) was used as the substrate. It was observed that butanol production from OPLP-UW (unwashed) and OPLP-W (washed) reached 8.16 and $1.69 \mathrm{~g} / \mathrm{L}$, respectively, in SHF. The results showed that ABE production in SHF from OPLP-UW prevents an "acid crash" as compared the OPLP-W. In SSF process, the "acid crash" occurred for both OPLP-W and OPLP-UW. The inhibitory extractable lignin intensified the "acid crash" for OPLP-UW and resulted in less ABE production than OPLP-W. The addition of detoxified prehydrolysates in SSF processes shortened the fermentation time and could potentially prevent the "acid crash".

Conclusions: The results suggested that the residual extractable lignin in high sugar concentration could help ABE production by lowering the metabolic rate and preventing "acid crash" in SHF processes. However, it became unfavorable in SSF due to its inhibition of both enzymatic hydrolysis and ABE fermentation with low initial sugar concentration. It is essential to remove extractable lignin of substrates for ABE production in SSF processes. Also, a higher initial sugar concentration is needed to prevent the "acid crash" in SSF processes.
\end{abstract}

Keywords: Fermentation, Residual extractable lignin, Acetone-butanol-ethanol, Acid crash

\section{Background}

Lignocellulosic biomass has great potential to replace petroleum-based liquid fuels and chemicals, thereby addressing our national needs for energy independence and domestic jobs, as well as environmental issues

\footnotetext{
*Correspondence: suanshi@cau.edu.cn; tumg@ucmail.uc.edu

${ }^{2}$ Engineering Laboratory for AgroBiomass Recycling \& Valorizing, College of Engineering, China Agricultural University, Beijing 100083, China

${ }^{3}$ Department of Chemical and Environmental Engineering, University of Cincinnati, Cincinnati, OH 45221, USA

Full list of author information is available at the end of the article
}

[1-3]. Butanol is one of the promising alternative biofuels, which can be produced from biomass [4]. Butanol production along with acetone and ethanol from sugars by Clostridium is known as "acetone-butanol-ethanol (ABE) fermentation" [5]. The fermentation produces butyrate and acetate at the beginning (acidogenic phase), in which the excess electrons are used to reduce $\mathrm{H}^{+}$to $\mathrm{H}_{2}$. Butanol, acetone, and ethanol start to be produced in the second phase (solventogenic phase) $[6,7]$. Solventogenesis typically is accompanied by sporulation. In batch $\mathrm{ABE}$ fermentation, "acid crash" occasionally 
occurred when fermentation is performed without $\mathrm{pH}$ control [8]. When this occurs, excess of acids is produced and the switch from the acidogenic phase to the solventogenic phase stopped [9]. The glucose consumption, acid production, and $\mathrm{ABE}$ generation are also terminated [8]. Previous studies suggested "acid crash" takes place with $C$. beijerinckii under the high concentration of undissociated acids (57-60 mM) [8]. It has been reported that solvent production by $C$. acetobutylicum ceased when formic acid accumulated to $0.5-1.24 \mathrm{mM}$ [10]. To prevent the "acid crash", several strategies have been developed by introducing $\mathrm{pH}$ control or by lowering the metabolic rate $[11,12]$. Buffering the initial $\mathrm{pH}$ at 5.0 (with sodium acetate) produced the highest butanol concentration of $12.3 \mathrm{~g} / \mathrm{L}$ by C. acetobutylicum at $72 \mathrm{~h}$ [12]. Incubation C. carboxidivorans at a lower temperature of $25{ }^{\circ} \mathrm{C}$ resulted in higher alcohol titers due to the lower metabolic rates [11]. Lowering yeast extract concentration (nutrients) reduced acid production rate and enabled solventogenesis to persist for a longer time with higher ABE concentration [8]. As a result, "acid crash" can be prevented by lowering the acid production rate or by providing less desirable growing conditions.

As far as we know, "acid crash" in ABE fermentation with lignocellulosic biomass has not been reported. $\mathrm{ABE}$ fermentation from enzymatic hydrolysate of pretreated corncobs has shown higher ABE yield and butanol concentration $(12.3 \mathrm{~g} / \mathrm{L})$ than mixed sugar control, which indicated hydrolysates may contain stimulating compounds to improve ABE fermentation [13]. Different processes have been used to ferment pretreated biomass to butanol, including separate hydrolysis and fermentation (SHF) and simultaneous saccharification and fermentation (SSF). Sasaki et al. reported an ABE production of $15.29 \mathrm{~g} / \mathrm{L}$ in SHF process versus $13.41 \mathrm{~g} / \mathrm{L}$ in SSF process from steam-exploded wood chips [14]. Butanol production from wheat straw by SSF using $C$. beijerinckii has been reported to produce $21.4 \mathrm{~g} / \mathrm{L} \mathrm{ABE} \mathrm{[15],} \mathrm{and} \mathrm{it}$ should be noted pretreated substrates have been washed with water. The effect of lignin presence on butanol production by $C$. acetobutylicum has been investigated with cellobiose as the carbon source, in which they found lignin $(1 \mathrm{~g} / \mathrm{L})$ delayed and decreased butanol production and promoted the accumulation of acetic and butyric acids [16].

Due to the low temperature limiting the hydrolysis rate in SSF, the productivity might be lower than the fermentation step in SHF. It is reported butanol production in SSF was $24 \mathrm{~h}$ slower than SHF since the sugar in SHF process is readily available to initiate the acid production once the clostridia inoculum was induced [17]. It has been reported the reassimilation of acids to solvents ceased when the remaining sugar was low and thus more acids were observed when lower sugar was applied [17, 18]. The low sugar concentration might also affect the phase transition from acidogenesis to solventogenesis in SSF process [17]. So, to increase the available sugar in SSF is critical to $A B E$ fermentation, which may be achieved by increasing the substrate concentration and enzyme activity [19], improving the pretreatment efficiency to increase the accessibility of substrate, and supplementing sugar-rich prehydrolysates.

The objective of this study is to assess the effect of residual lignin in organosolv-pretreated substrates on $\mathrm{ABE}$ production. The effect of lignin on enzymatic hydrolysis has been extensively studied due to its strong interaction with enzymes [20, 21]. Previous studies reported that ethanol organosolv lignin (EOL) should be maintained in substrates and solvent washing after pretreatment was not necessary for enzymatic hydrolysis [22]. However, the impact of residual lignin on subsequent microbial fermentation was not well understood. Recently, Li et al. reported a negative correlation between lignin level and ethanol production, indicating the inhibitory effect of lignin on ethanol fermentation [23]. In this study, the effect of ethanol washing on $\mathrm{ABE}$ production from organosolv-pretreated loblolly with SHF and SSF processes will be examined. It is hypothesized that the residual extractable lignin (similar to EOL) on pretreated substrates can prevent the "acid crash" in ABE fermentation by lowering the metabolic rate and reducing the acid production rate. It is also possible that the lower temperature $\left(35^{\circ} \mathrm{C}\right)$ in SSF process can slow down the enzymatic hydrolysis and prevent the "acid crash". The effect of ethanol washing on enzymatic hydrolysis of organosolv-pretreated loblolly pine (OPLP) will be compared between the washed substrates (OPLP-W) and the unwashed substrates (OPLP-UW). The effect of ethanol washing on ABE production in SHF and SSF processes will be also compared between OPLP-W and OLPL-UW. In addition, the detoxified prehydrolysates will be supplemented into SSF process to evaluate its effect on ABE fermentation.

\section{Results and discussion}

Effect of ethanol washing on enzymatic hydrolysis of OPLP The ethanol extractives content (9.64\%) in OPLP-UW were much higher than those in the untreated biomass $(1.18 \%)$ (Table 2). The ethanol extractives were reduced to $0.79 \%$ in OPLP after ethanol washing (Table 2). During the organosolv pretreatment, lignin was depolymerized and a significant amount of $\beta$-o- 4 linkages was cleaved which was catalyzed by acids $[24,25]$. The depolymerized lignin was precipitated on the surface of the wood fibers and it can be largely removed by ethanol washing $[22,26]$. Lai et al. have reported that the ethanolwashed extractives were similar to ethanol organosolv 
lignin (EOL) by ${ }^{13} \mathrm{C}$-NMR [22]. To examine the effect of ethanol washing on enzymatic digestibility of OPLP, the pretreated substrates with and without ethanol washing were hydrolyzed and compared under the SHF and SSF conditions (Fig. 1). The results showed the 72-h hydrolysis yield of OPLP-W and OPLP-UW was similar (90\%) (Fig. 1a). The addition of precipitated organosolv lignin $(0.3 \mathrm{~g})$ also did not change the hydrolysis yield of OPLPW. It indicated that ethanol washing did not have any positive or negative effects on substrates digestibility at the SHF conditions $\left(50{ }^{\circ} \mathrm{C}\right.$ and $\left.\mathrm{pH} 4.8\right)$. Previous studies reported that EOL from loblolly pine had a negative effect on enzymatic hydrolysis of OPLP, in which the enzyme loading was $5 \mathrm{FPU} / \mathrm{g}$ glucan [27]. High enzyme loading (25 FPU/g glucan) in this study probably overcame the negative effect of EOL on enzymatic hydrolysis. It reduced the effect of nonproductive binding between cellulase and lignin by providing sufficient enzyme active sites [28]. The residual lignin adsorbed on the additional active sites offered by extra enzyme compared to low
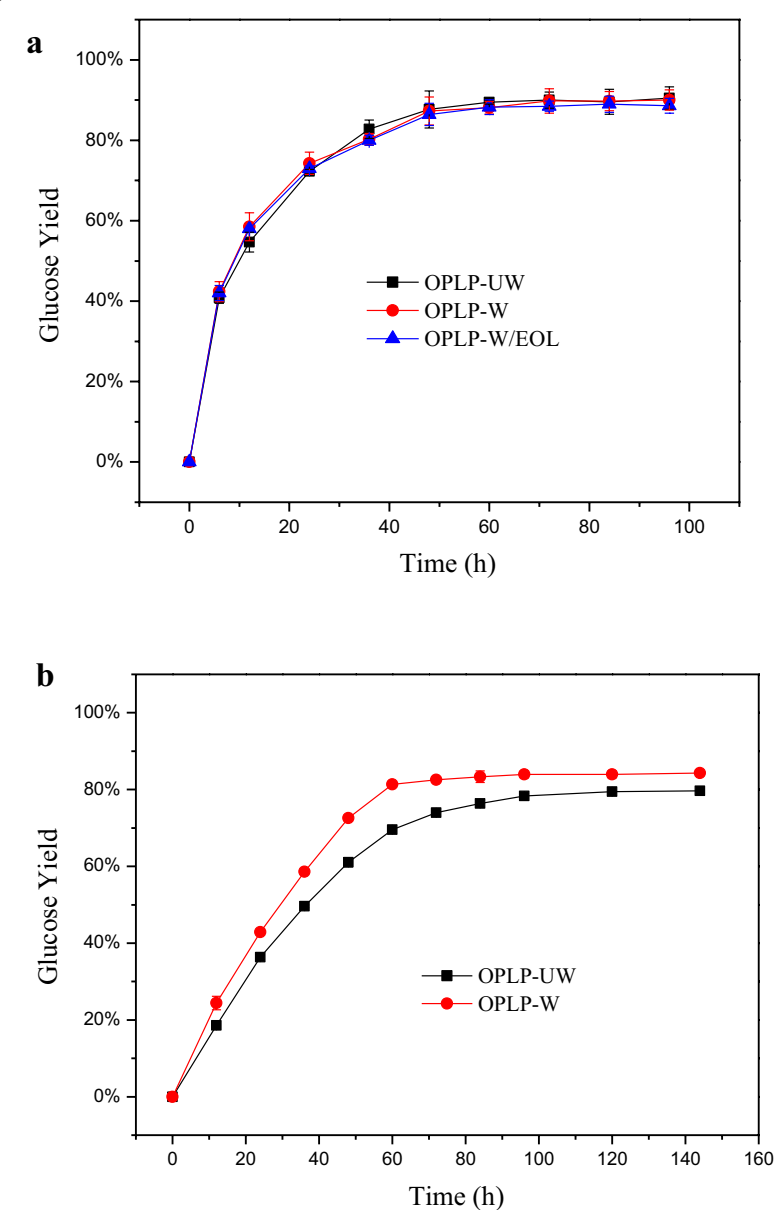

Fig. 1 Effect of ethanol washing on enzymatic hydrolysis of OPLP: a $50^{\circ} \mathrm{C}$ and $\mathrm{pH} 4.8$ and $\mathbf{b} 35^{\circ} \mathrm{C}$ and $\mathrm{pH} 6.0$ enzyme loading and resulted in the negligible negative effect of residual lignin on enzymatic hydrolysis. Enzyme dosage below $10 \mathrm{FPU} / \mathrm{g}$ cellulose is usually considered as low enzyme loading $[29,30]$. The National Renewable Energy Laboratory (NREL) in the United States set the enzyme loading to $19-33 \mathrm{mg}$ protein/g cellulose (equivalent to 15-20 FPU/g cellulose) when building the ethanol cost evaluation model, which is the normal range for bioconversion of lignocellulosic biomass [31, 32]. A minimum cellulase (Celluclast 1.5) loading of $32 \mathrm{mg}$ protein/g cellulose is required for efficient hydrolysis ( $70 \%$ glucan conversion) of organosolv-pretreated lodgepole pine [33]. A slightly high enzyme loading (25 FPU/g glucan) applied in this study is to minimize the rate-limiting effect of enzymatic hydrolysis during the SSF process. Therefore, by eliminating the enzyme hydrolysis impact on SSF, the effect of extractable lignin on ABE production could be explored. However, the practice of reducing enzyme loading could be carried out in the future upon obtaining a better understanding of how the extractable lignin affects $A B E$ production in SHF and SSF processes.

While for the enzymatic hydrolysis of OPLP-W and OPLP-UW at the SSF conditions $\left(35{ }^{\circ} \mathrm{C}\right.$ and $\mathrm{pH}$ 6), the $72 \mathrm{~h}$ hydrolysis yield of OPLP-W and OPLP-UW was $82.5 \%$ and $73.9 \%$, respectively (Fig. $1 \mathrm{~b}$ ), which were lower than those at the SHF conditions $\left(50{ }^{\circ} \mathrm{C}\right.$ and $\mathrm{pH}$ 4.8). Notably, the OPLP-UW had even lower hydrolysis yield compared to OPLP-W under the test conditions. The lower temperature $\left(35^{\circ} \mathrm{C}\right)$ also resulted in the lower initial hydrolysate rate (Fig. 1). According to the adsorption kinetics of cellulase on the cellulose and lignin, the decrease of temperature reduced the adsorption of cellulase on both cellulose and lignin, however, the reduction was much more considerable for cellulose than lignin [28, 34]. The lignin had a higher affinity to cellulase than cellulose $[28,35]$. These factors made more cellulase adsorbed on lignin rather than cellulose and the negative effect of extractable lignin on enzymatic hydrolysis was exhibited at the lower temperature. In addition to the lower temperature, higher $\mathrm{pH}$ (6.0) could be another main reason for lower hydrolysis yield and initial rate. Similar results have been reported that higher $\mathrm{pH}$ (6.0) reduced the hydrolysis yield of organosolv-pretreated loblolly pine at $10 \mathrm{FPU} / \mathrm{g}$ glucan [36]. The $\mathrm{pH}$ increase from 5 to 7 could result in less adsorption of cellulase on cellulose substrate [34] and decrease the enzyme activity; $\mathrm{pH} 4.8$ has long been suggested for cellulase enzymatic hydrolysis [37]. Adding $\mathrm{CaCO}_{3}$ to control $\mathrm{pH}$ in the hydrolysis solution could also contribute to the decrease in enzyme activity. It is reported that the inhibition of $\mathrm{CaCO}_{3}$ to enzymatic hydrolysis possibly caused by nonproductive enzyme binding on $\mathrm{CaCO}_{3}$ particles and deactivation of enzyme resulting from enzyme aggregation by 
dissociated calcium ion [38, 39]. The observation that the removal of extractable lignin from the examined substrate (softwood) by ethanol washing improved the enzymatic hydrolysis appears not to agree with the effect of EOL from hardwood, but is consistent with the effect of EOL from softwood by Lai et al. [22, 40]. They reported a contrasting effect of hardwood and softwood organosolv lignin, where EOL from hardwood enhanced enzyme hydrolysis and EOL from softwood inhibited enzymatic hydrolysis. Huang et al. investigated the reason why the lignin from two types of sources exerted opposite effects [27]. They found a strong correlation between hydrophobicity and zeta potential of EOL and enzymatic hydrolysis yield, indicating the stimulation or inhibition effect of lignin is controlled by the combination of hydrophobicity and zeta potential.

\section{Effect of ethanol washing on ABE production in SHF processes}

Under SHF conditions, the ethanol washing showed no effect on the 72-h hydrolysis yield of organosolvpretreated loblolly pine at current enzyme loading (25 FPU/g glucan). However, the subsequent effect on $\mathrm{ABE}$ fermentation of the hydrolysates from ethanol-washed substrates is unknown. Therefore, three enzymatic hydrolysates from OPLP-UW, OPLP-W and OPLP-W/EOL (plus precipitated EOL) were compared in $A B E$ fermentation (Fig. 2). It was observed that butanol production from the OPLP-UW hydrolysate was $8.16 \mathrm{~g} / \mathrm{L}$ with a yield of $0.14 \mathrm{~g} / \mathrm{g}$ at $96 \mathrm{~h}$, and the residual glucose was $5.06 \mathrm{~g} / \mathrm{L}$ (Fig. 2a). The initial glucose consumption rate (within $36 \mathrm{~h}$ ) was low at $0.30 \mathrm{~g} / \mathrm{L} / \mathrm{h}$. The organism began to accumulate butyric acid at $24 \mathrm{~h}$ and acetic acid at $48 \mathrm{~h}$. Butyric acid peaked $(5.81 \mathrm{~g} / \mathrm{L})$ at $72 \mathrm{~h}$ and then gradually decreased to $3.89 \mathrm{~g} / \mathrm{L}$ at $96 \mathrm{~h}$. Butanol production began late at $36 \mathrm{~h}$ in the fermentation. The acetone and ethanol reached 2.22 and $1.52 \mathrm{~g} / \mathrm{L}$ at $96 \mathrm{~h}$, respectively. While for the ABE fermentation with the OPLP-W (Fig. 2b), the initial glucose consumption rate (within $36 \mathrm{~h}$ ) was fast at $0.69 \mathrm{~g} / \mathrm{L} / \mathrm{h}$, but glucose consumption and ABE production ceased at $48 \mathrm{~h}$. The initial glucose concentration was nearly $50 \mathrm{~g} / \mathrm{L}$. The organism began to accumulate butyric acid at $12 \mathrm{~h}$ and quickly reached $6.23 \mathrm{~g} / \mathrm{L}$ at $36 \mathrm{~h}$ and did not decrease further. Butanol production began from $36 \mathrm{~h}$, but stopped at $48 \mathrm{~h}$ with a low concentration of $1.69 \mathrm{~g} / \mathrm{L}$. The butyric acid and acetic acid were $6.44 \mathrm{~g} / \mathrm{L}$ and $4.24 \mathrm{~g} / \mathrm{L}$ at $48 \mathrm{~h}$ and then leveled off. The residual glucose was $19.72 \mathrm{~g} / \mathrm{L}$ at $48 \mathrm{~h}$ and did not change further. It indicated $A B E$ production from the OPLP-W hydrolysate suffered an "acid crash", in which solventogenesis was initiated but the metabolic activity (glucose consumption, acid production, and $\mathrm{ABE}$ production) ceased within a short time (Fig. 2b). The butyric acid production rate $(2.92 \mathrm{mM} / \mathrm{h}$, between 12 and $36 \mathrm{~h})$ was much higher than that $(0.59 \mathrm{mM} / \mathrm{h})$ in ABE fermentation with OPLP-UW hydrolysate. The toxic butyric acid was generated quickly inside cells and inhibited solventogenesis and ceased the ABE production. It has been suggested "acid crash" occurs in $\mathrm{pH}$-uncontrolled $\mathrm{ABE}$ fermentation when undissociated acids exceed 57-60 mM [8]. In this study, $\mathrm{pH}$ was controlled by $\mathrm{CaCO}_{3}$ and the $\mathrm{pH}$ was kept in the range of 5 to 6 over the fermentation time. The concentration of the total acids reached $144 \mathrm{mM}$ at $48 \mathrm{~h}$, which included undissociated acids and dissociated acids. It has been proposed previously that the high concentration of dissociated acids rather than undissociated acids are responsible for the inhibition of solventogenesis at some ABE fermentation [8]. The comparison of ABE fermentation with OPLP-W and OPLP-UW hydrolysates indicated that the metabolism of the organism could be altered by ethanol washing or the presence of extractable lignin (after pretreatment). We hypothesized that extractable lignin (similar to EOL) can inhibit the glucose consumption and acid production rates thus prevent the "acid crash" in ABE fermentation. To test this hypothesis, precipitated EOL from organosolv pretreatment was added into $A B E$ fermentation of the OPLP-W hydrolysates (Fig. 2c). The initial glucose consumption rate (within $36 \mathrm{~h}$ ) was fast at $0.52 \mathrm{~g} / \mathrm{L} / \mathrm{h}$, but glucose consumption and $\mathrm{ABE}$ production continued until $84 \mathrm{~h}$. The organisms began to produce butyric acid at $12 \mathrm{~h}$ and increased to $4.67 \mathrm{~g} / \mathrm{L}$ at $36 \mathrm{~h}$ and reached $5.76 \mathrm{~g} / \mathrm{L}$ at $48 \mathrm{~h}$, then decreased due to the shift from acidogenic phase to solventogenic phase. Butanol production began from $36 \mathrm{~h}$ and reached $7.60 \mathrm{~g} / \mathrm{L}$ at $96 \mathrm{~h}$. The acetic acid was $4.17 \mathrm{~g} / \mathrm{L}$ at $60 \mathrm{~h}$ and then leveled off. The acetone and ethanol reached 2.23 and $0.73 \mathrm{~g} / \mathrm{L}$ at $96 \mathrm{~h}$, respectively. The residual glucose was $4.31 \mathrm{~g} / \mathrm{L}$ at $96 \mathrm{~h}$, which was similar to that from the ABE fermentation of OPLP-UW hydrolysates. The results demonstrated that the presence of extractable lignin could lower the metabolic rate and prevent the "acid crash" in ABE fermentation. Different approaches have been suggested previously to prevent "acid crash" by $\mathrm{pH}$ controlling or lowering the metabolic rate. Lowering yeast extract concentrations $(0.05 \mathrm{~g} / \mathrm{L})$ in the medium resulted in higher $\mathrm{ABE}$ production of $134 \mathrm{mM}$, low sugar uptake and acid product rates [8]. Overexpressing aldehyde/alcohol dehydrogenase and CoA-transferase in Clostridium beijerinckii was able to prevent "acid crash" and increase butanol production [41]. Syngas fermentation with Clostridium carboxidivorans at a low temperature has been reported to enhance butanol production by 

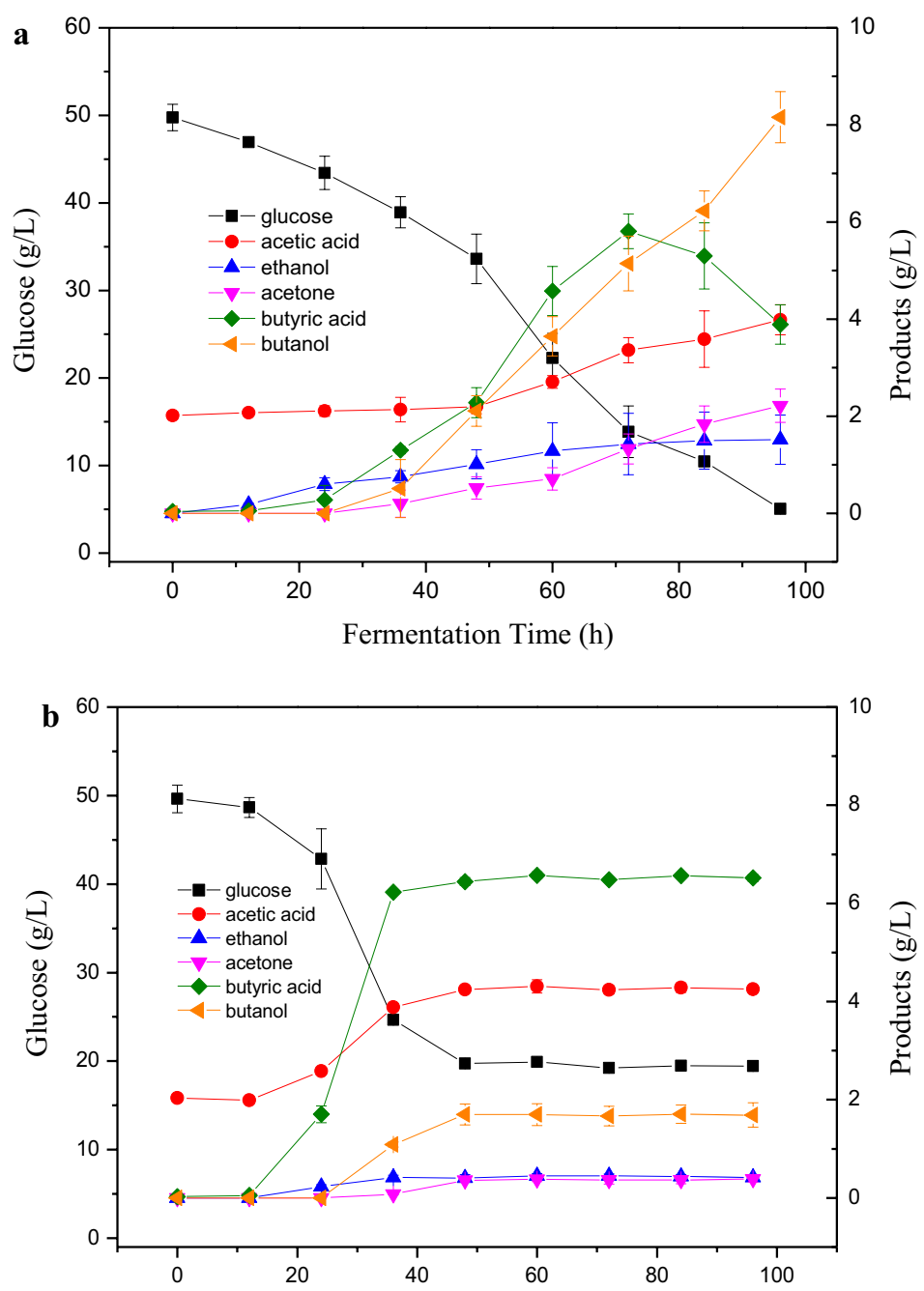

Fermentation Time (h)

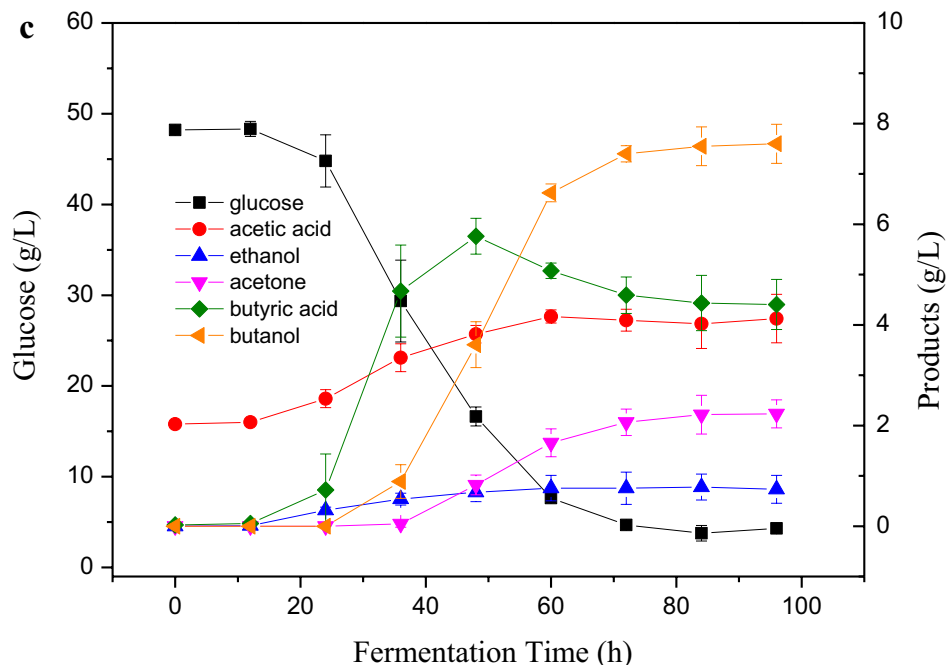

Fig. 2 ABE fermentation of the hydrolysates from OPLP-UW (a), OPLP-W (b) and OPLP-W/EOL (c) 
lowering metabolic rates at $25{ }^{\circ} \mathrm{C}$ [11]. In this study, we found the inhibitory extractable lignin could be potentially effective to prevent the "acid crash" in ABE
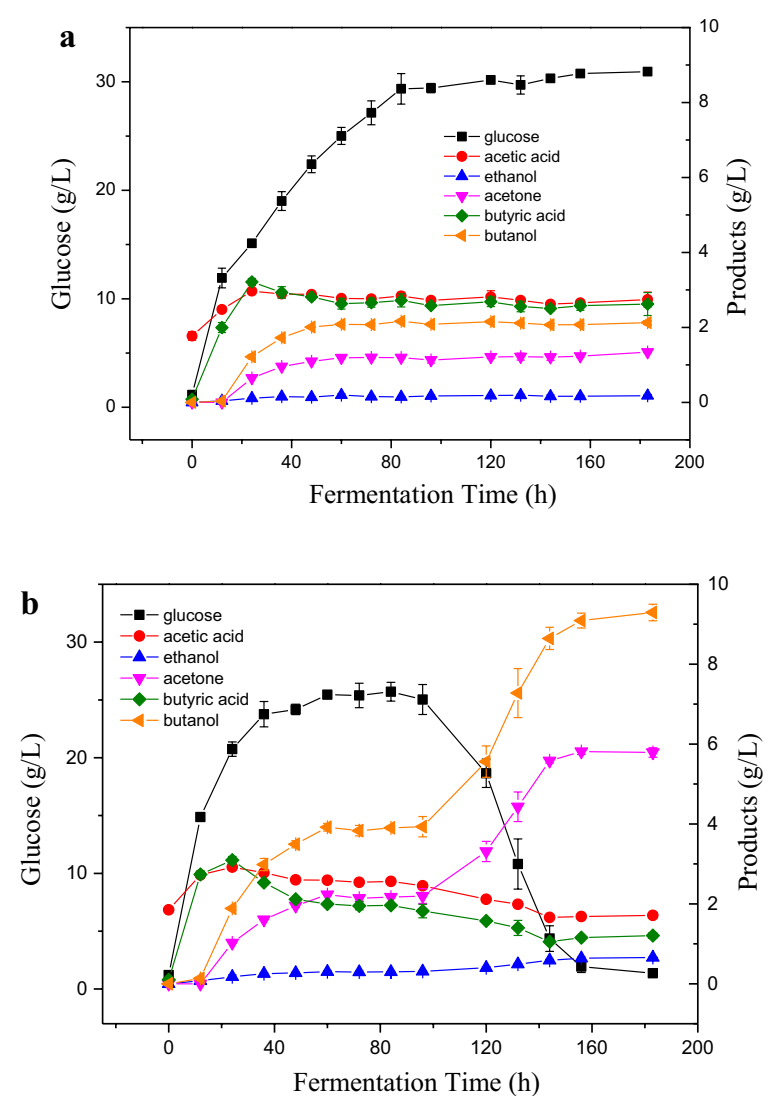

(b

Fig. 3 ABE production with OPLP-UW (a) and OPL P-W (b) in SSF process fermentation by lowering the glucose uptake and acid production rates.

\section{Effect of ethanol washing on ABE production in SSF processes}

ABE production with OPLP-UW and OPLP-W in SSF was compared (Fig. 3 and Table 1). In both cases, $A B E$ fermentation suffered "acid crash" after $60 \mathrm{~h}$, and butanol, ethanol, and acetone production ceased. However, the $\mathrm{ABE}$ production recommenced at $96 \mathrm{~h}$ for OPLP-W. Specifically for OPLP-UW, acetic acid and butyric acid quickly reached 2.97 and $3.21 \mathrm{~g} / \mathrm{L}$ at $24 \mathrm{~h}$, respectively. The butanol reached $1.22 \mathrm{~g} / \mathrm{L}$ at $24 \mathrm{~h}$. The glucose concentration reached $15.11 \mathrm{~g} / \mathrm{L}$ at $24 \mathrm{~h}$ and it was much lower than the initial glucose concentration in the SHF process. For OPLP-W, acetic acid and butyric acid reached 2.92 and $3.09 \mathrm{~g} / \mathrm{L}$ at $24 \mathrm{~h}$, respectively, which are similar to those in OPLP-UW. The butanol reached $1.89 \mathrm{~g} / \mathrm{L}$ at $24 \mathrm{~h}$. The glucose concentration $(20.75 \mathrm{~g} / \mathrm{L})$ was $37 \%$ higher than that in OPLP-UW at $24 \mathrm{~h}$. This suggested that ethanol washing significantly increased the hydrolyzability of OPLP-W as compared to OPLPUW, which provided more initial glucose in SSF process. Cells produced more butanol $(3.92 \mathrm{~g} / \mathrm{L})$ and less butyric acid $(2.00 \mathrm{~g} / \mathrm{L})$ from OPLP-W than that from OPLP-UW $(2.08 \mathrm{~g} / \mathrm{L}$ butanol and $2.63 \mathrm{~g} / \mathrm{L}$ butyric acid) at $60 \mathrm{~h}$. This indicated that initial sugar concentration significantly affected the solvent and acid production; cells appear to produce more acids and fewer solvents when the initial sugar concentration is low. A similar observation has been reported previously, where only $2.93 \mathrm{~g} / \mathrm{L}$ of solvents were produced from $20 \mathrm{~g} / \mathrm{L}$ of glucose as compared to $8.77 \mathrm{~g} / \mathrm{L}$ of solvents from $40 \mathrm{~g} / \mathrm{L}$ of glucose [42].

In addition, the metabolic activity including acid production and $\mathrm{ABE}$ production ceased at $60 \mathrm{~h}$ for

Table 1 Acetone-butanol-ethanol fermentation in SHFand SSF

\begin{tabular}{|c|c|c|c|c|c|c|}
\hline & \multicolumn{3}{|l|}{ SHF } & \multicolumn{3}{|l|}{ SSF } \\
\hline & OPLP-UW & OPLP-W & OPLP-W/EOL & OPLP-UW & OPLP-W & OPLP-W/PH \\
\hline Residual glucose (g/L) & $5.06 \pm 0.13$ & $19.42 \pm 0.51$ & $4.30 \pm 0.25$ & $30.93 \pm 0.02$ & $1.36 \pm 0.33$ & $0.59 \pm 0.36$ \\
\hline Butanol (g/L) & $8.16 \pm 0.53$ & $1.69 \pm 0.25$ & $7.60 \pm 0.39$ & $2.13 \pm 0.05$ & $9.29 \pm 0.21$ & $10.51 \pm 0.18$ \\
\hline Butanol yield (g/g) & $0.14 \pm 0.01$ & $0.03 \pm 0.00$ & $0.13 \pm 0.01$ & $0.04 \pm 0.00$ & $0.16 \pm 0.00$ & $0.15 \pm 0.00$ \\
\hline $\mathrm{ABE}(\mathrm{g} / \mathrm{L})$ & $11.89 \pm 0.12$ & $2.66 \pm 0.33$ & $10.56 \pm 0.22$ & $3.65 \pm 0.05$ & $15.74 \pm 0.33$ & $18.29 \pm 0.22$ \\
\hline ABE yield (g/g) & $0.20 \pm 0.00$ & $0.04 \pm 0.01$ & $0.18 \pm 0.00$ & $0.06 \pm 0.00$ & $0.27 \pm 0.01$ & $0.26 \pm 0.01$ \\
\hline Butyric acid (g/L) & $3.89 \pm 0.41$ & $6.52 \pm 0.07$ & $4.41 \pm 0.50$ & $2.62 \pm 0.31$ & $1.21 \pm 0.07$ & $1.68 \pm 0.04$ \\
\hline Acetic acid (g/L) & $3.99 \pm 0.31$ & $4.25 \pm 0.05$ & $4.13 \pm 0.48$ & $2.74 \pm 0.20$ & $1.71 \pm 0.06$ & $1.80 \pm 0.01$ \\
\hline Acid crash & No & Yes & No & Yes & $Y_{e s}^{b}$ & No \\
\hline
\end{tabular}

Data are presented as the final point in fermentation processes, SHF, 96 h; SSF for OPLP-UW and OPLP-W, 183 h; SSF for OPLP-W/PH, 132 h. The value was presented as mean value \pm standard deviation

a OPLP-W/PH: ethanol-washed OPLP with detoxified prehydrolysates

b Fermentation recommenced after acid crash 
OPLP-UW, the glucose uptake probably also ceased (Fig. 3a). The total acid concentration was $76 \mathrm{mM}$ at $60 \mathrm{~h}$ and did not change until $183 \mathrm{~h}$. The residual extractable lignin not only inhibited the enzymatic hydrolysis, but also inhibited the microbial fermentation. Unexpectedly for OPLP-W, the solventogenesis and glucose uptake recommenced were at $96 \mathrm{~h}$. All the glucose was consumed, and the final butanol concentration reached $9.29 \mathrm{~g} / \mathrm{L}$ at $183 \mathrm{~h}$. The total ABE concentration reached $15.74 \mathrm{~g} / \mathrm{L}$. During the phase of metabolic inactivity (60$96 \mathrm{~h}$ ), the total acid concentration had slowly decreased from 66 to $61 \mathrm{mM}$ [8]. Similarly, ABE recommencement after "acid crash" has been reported on pure glucose fermentation before, when the total undissociated acids dropped below a threshold of $55 \mathrm{mM}$. It should be noticed that the final acetone concentration reached $5.79 \mathrm{~g} / \mathrm{L}$, which was much higher than those in the SHF process. The results indicated that residual extractable lignin in OPLP-UW inhibited ABE fermentation and potentially intensified "acid crash" in the SSF processes. Comparing the ABE fermentation in SHF and SSF processes, the effect of residual extractable lignin was beneficial in SHF on ABE production by slowing the glucose consumption in $\mathrm{ABE}$ fermentation at high initial glucose concentration $(50 \mathrm{~g} / \mathrm{L})$, but it became unfavorable in SSF due to its inhibition on both enzymatic hydrolysis and $\mathrm{ABE}$ fermentation with low initial sugar concentration (around $0 \mathrm{~g} / \mathrm{L}$ ). In SHF processes, high sugar concentration $(50 \mathrm{~g} / \mathrm{L})$ was available for fast acidogenesis. The presence of extractable lignin in OPLP-UW hydrolysate inhibited microbial metabolic activity and decreased the metabolic rate. Subsequently, the "acid crash" was avoided in OPLU-UW and OPLP-W/EOL hydrolysates. In this case, extractable residual lignin helped ABE fermentation in SHF processes. In SSF processes, the low initial sugar concentration resulted in an "acid crash" for both OPLP-UW and OPLP-W substrates after $60 \mathrm{~h}$. The inhibition of extractable lignin on enzymatic hydrolysis of OPLP-UW made it even less favorable for ABE production due to the lower sugar concentration. The inhibition of extractable lignin on microbial metabolic activity further intensified the "acid crash" for OPLP-UW. This suggested that inhibitory extractable lignin could deep "acid crash" in low sugar concentration for ABE production. Without the presence of extractable lignin in OPLP$\mathrm{W}$, the butyric and acetic acids were slowly consumed in the "acid crash" phase, which in turn enabled the solventogenesis and glucose uptake to recommence at $96 \mathrm{~h}$. Therefore, it is essential to remove extractable lignin of substrates for ABE production in SSF processes. And a higher initial sugar concentration is needed to prevent the "acid crash" in the SSF processes.
The residual lignin was observed to aid $\mathrm{ABE}$ production in the SHF process, but hinder the ABE production in the SSF process. It is considered to affect the occurrence of "acid crash" together with initial sugar concentration. However, the threshold of sugar concentration that resulted in "acid crash" in both SHF and SSF is not clear and of interest. In the meantime, the presence of lignin levels is also a critical variable affecting the onset of "acid crash". The combination effect of lignin and initial sugar concentration was also examined in the next part of experiment with the addition of prehydrolysates. Under the test experiment, it is estimated the initial sugar concentration between 5 and $20 \mathrm{~g} / \mathrm{L}$ could potentially avoid the acid crash in SHF or SSF processes. The initial sugar concentration in SHF or SSF could be changed by varying solid loading. It is speculated that the $\mathrm{ABE}$ production from OPLP-W might be higher than OPLP-UW in SHF process when the solid loading is lower than the current study. Also, the "acid crash" might be avoided by increasing the solid loading of OPLP-W and improving the enzymatic hydrolysis in SSF process. The improvement of enzymatic hydrolysis could be achieved by increasing enzyme dosage or adding additives.

\section{Effect of adding detoxified prehydrolysates on $A B E$ fermentation in SSF processes}

Considering the removal of residual extractable lignin in SSF gave the best ABE production (Table 1), detoxified prehydrolysates was supplemented into OPLP-W in SSF processes. Two-step detoxification has been used to detoxify the prehydrolysates from organosolv pretreatment [43]. The final butanol and ABE concentration in OPLP-W with prehydrolysate (OPLP-W/PH) reached $10.51 \mathrm{~g} / \mathrm{L}$ and $18.29 \mathrm{~g} / \mathrm{L}$, respectively. No "acid crash" occurred in this case (Fig. 4a). It suggested that adding detoxified prehydrolysates into SSF processes alleviated the "acid crash" for ABE fermentation due to the increase of initial sugar concentration. The acetone and ethanol reached 6.13 and $1.53 \mathrm{~g} / \mathrm{L}$ at $96 \mathrm{~h}$, respectively. The residual glucose was only $0.59 \mathrm{~g} / \mathrm{L}$ at $132 \mathrm{~h}$. The organism began to produce butyric and acetic acids at $12 \mathrm{~h}$. Butyric acid peaked $(2.09 \mathrm{~g} / \mathrm{L})$ at $24 \mathrm{~h}$ and then decreased to $1.14 \mathrm{~g} / \mathrm{L}$ at $36 \mathrm{~h}$ and gradually increased to $1.68 \mathrm{~g} / \mathrm{L}$ at $132 \mathrm{~h}$. The butyric acid maximum concentration was $35 \%$ less than that from OPLP-W without prehydrolysates in the previous SSF process. Butanol production from OPLP-W/PH began at $24 \mathrm{~h}$ and slowed at $48 \mathrm{~h}$, but it recommenced at $60 \mathrm{~h}$ quickly. The ABE fermentation from OPLP-W/PH completed within $96 \mathrm{~h}$, which was $60 \mathrm{~h}$ shorter than that from OPLP-W without prehydrolysates in the SSF process (Fig. 3b). These results indicated the addition of sugars from prehydrolysates 

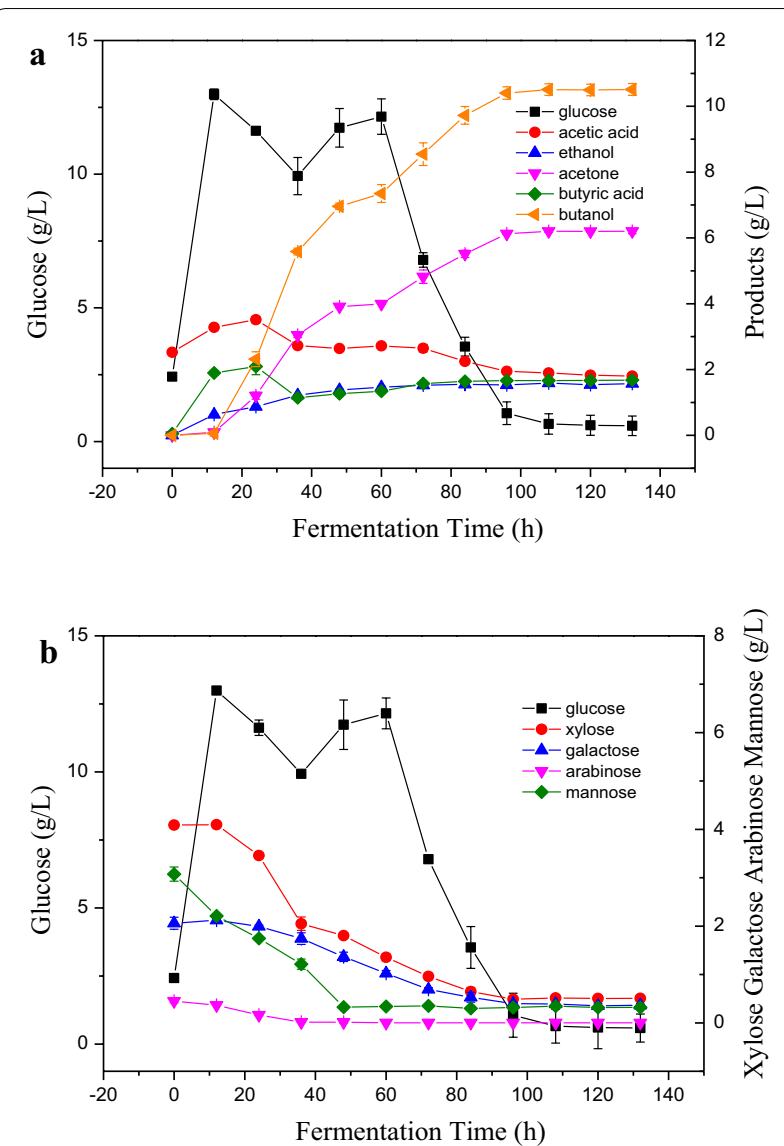

Fig. 4 Effect of adding detoxified prehydrolysates on ABE production with OPLP-W in SSF process

potentially prevented the "acid crash" and helped the $\mathrm{ABE}$ fermentation in the SSF processes.

After adding prehydrolysates into OPLP-W, the initial glucose, xylose, mannose, galactose concentration in the aqueous phase was 2.06, 4.09, 3.08 and $2.42 \mathrm{~g} / \mathrm{L}$, respectively (Fig. 4b). The released glucose reached $12.99 \mathrm{~g} / \mathrm{L}$ at $12 \mathrm{~h}$ and then decreased to $9.93 \mathrm{~g} / \mathrm{L}$ at $36 \mathrm{~h}$. After that, the glucose concentration increased to $12.15 \mathrm{~g} / \mathrm{L}$ at $60 \mathrm{~h}$, then decreased again quickly to $1.06 \mathrm{~g} / \mathrm{L}$ at $96 \mathrm{~h}$. The glucose concentration at $12 \mathrm{~h}$ was $13 \%$ lower than that without prehydrolysates in the previous SSF (Fig. 3b). This probably was caused by the inhibition resulting from residual undetoxified inhibitors in prehydrolysates. It is reported that lignin-derived aromatic compounds induced inhibition or complete inactivation of enzymes [20]. The initial sugars in the prehydrolysates could also inhibit the enzymatic hydrolysis. Previously, sugar inhibition on cellulases and beta-glucosidase has been reported on enzymatic hydrolysis of softwood substrates [44]. The solventogenic clostridia are capable of using both hexose and pentose as carbon source for ABE production. It was observed that mannose was used firstly and quickly, followed by xylose. All the available sugars were assimilated by Clostridium at the end of fermentation, leaving an insignificant amount of residual sugars. The results suggested the prehydrolysates could reduce the $\mathrm{ABE}$ fermentation time in SSF processes, all the $\mathrm{C} 5$ and $\mathrm{C} 6$ could be consumed for ABE production and the "acid crash" could be potentially avoided.

In this study, the ABE production from OPLP-W and OPLP-UW was carried out in two different fermentation processes. Overall, the SSF process gave a higher ABE production $(15.74 \mathrm{~g} / \mathrm{L})$ compared to the SHF process $(11.89 \mathrm{~g} / \mathrm{L})$ due to the removal of glucose inhibition in SSF process. Although fermentation time for the SSF (156 h) was longer than the SHF ( $96 \mathrm{~h}$ ), the whole time of SHF was identical to SSF if the time for enzymatic hydrolysis $(72 \mathrm{~h}$ ) was taken into consideration. The residual extractable lignin showed a significant effect on ABE fermentation on OPLP-W and OPLP-UW. In SHF process, it prevented the "acid crash" by slowing the microbial metabolism and increased the $\mathrm{ABE}$ yield from $0.04 \mathrm{~g} / \mathrm{g}$ (OPLP-W) to $0.20 \mathrm{~g} / \mathrm{g}$ (OPLP-UW). However, in the SSF process, whereas the initial sugar concentration was low, the presence of residual extractable lignin intensified the "acid crash" and the ethanol-washed substrate (OPLP-W) resulted in higher ABE production than from OPLP-UW (15.74 g/L vs. $3.65 \mathrm{~g} / \mathrm{L})$. Also, the addition of prehydrolysates to OPLP-W further improved the ABE fermentation by prevention of "acid crash" and gave the highest ABE titer of $18.29 \mathrm{~g} / \mathrm{L}$.

\section{Conclusions}

The effect of residual extractable lignin in $\mathrm{ABE}$ fermentation of organosolv-pretreated loblolly pine has been compared in SHF and SSF processes. Unexpectedly, the extractable lignin in OPLP-UW and OPLP-W/EOL was observed to slow down the metabolic activity of clostridium and prevent the "acid crash" in SHF processes. The presence of residual extractable lignin enhanced the final butanol concentration compared to the OPLP-W. However, the extractable lignin did not help the ABE fermentation in SSF process and intensified the "acid crash". This is caused by the inhibition of lignin to both saccharification and fermentation. The removal of residual extractable lignin by ethanol washing is needed to reduce its inhibitory effect on ABE fermentation in SSF. The low initial sugar concentration in SSF process could be a possible reason for acid crash. The addition of prehydrolysates could potentially prevent the "acid crash" of ABE fermentation in SSF processes by increasing the initial sugar concentration. It also significantly shortened the fermentation time from $156 \mathrm{~h}$ to $96 \mathrm{~h}$ and improved the efficiency of lignocellulose by using the sugar dissolved in the aqueous phase. 


\section{Materials and methods}

\section{Chemicals and microorganisms}

Glucose and $\mathrm{NaOH}$ were purchased from VWR (West Chester, PA). $\mathrm{Ca}(\mathrm{OH})_{2}, \quad p$-aminobenzoic acid and $\mathrm{CH}_{3} \mathrm{COONH}_{4}$ were purchased from Alfa Aesar (Heysham, England). Thiamine was purchased from Alfa Aesar (Ward Hill, MA). Dowex 1X4 resin (chloride form) and biotin were purchased from Sigma-Aldrich (St. Louis, MO). $\mathrm{H}_{2} \mathrm{SO}_{4}(98 \%)$ and $\mathrm{NaCl}$ were purchased from VWR (West Radnor, PA). $\mathrm{K}_{2} \mathrm{HPO}_{4}, \mathrm{KH}_{2} \mathrm{PO}_{4}$, $\mathrm{MgSO}_{4} \cdot 7 \mathrm{H}_{2} \mathrm{O}, \mathrm{MnSO}_{4} \cdot \mathrm{H}_{2} \mathrm{O}, \mathrm{FeSO}_{4} \cdot 7 \mathrm{H}_{2} \mathrm{O}$ were purchased from Fisher Scientific (Fair Lawn, NJ). Citric acid was purchased from Mallinckrodt Chemicals (Phillipsburg, NJ). $\mathrm{CaCO}_{3}$ was purchased from EMD Chemicals (Gibbstown, NJ). Reinforced Clostridial Broth medium (RCM) was purchased from HIMEDIA laboratories (Mumbai, India). Cellic CTec 2 was obtained from Novozymes North America, Inc (Franklinton, UC). DI water was produced by the Barnstead Nanopure UV Ultrapure Water System (Thermo Fisher Scientific, Marietta, $\mathrm{OH}$ ).

Clostridium acetobutylicum ATCC 824 was used for butanol production. It was routinely stored as spores at $4{ }^{\circ} \mathrm{C}$ and treated by heat shock at $75{ }^{\circ} \mathrm{C}$ for $10 \mathrm{~min}$ followed by cooling down in an ice bath prior to cultivation. The RCM medium was sparged with nitrogen and then autoclaved at $121{ }^{\circ} \mathrm{C}$ for $15 \mathrm{~min}$. The heat-shocked cells were grown until the optical density (OD) reached 1.30 determined by an UV-vis spectrometer (Thermo Scientific, Madison, WI) at $600 \mathrm{~nm}$.

\section{Organosolv pretreatment}

Loblolly pine wood chips were collected by the Forest Products Laboratory at Auburn University and those free of barks and size of $1.0 \times 1.0 \mathrm{~cm}(\mathrm{~L} \times \mathrm{W})$ were selected for organosolv pretreatment. Wood chips (80 g, ovendry weight) were soaked in $65 \%(v / v)$ ethanol solution with $1.1 \%(w / w)$ sulfuric acid (on the basis of biomass dry weight) overnight (7:1 liquor/solid ratio) and then loaded into a 1-L Parr reactor (Parr Instrument Co., Moline, IL) to be treated at $170{ }^{\circ} \mathrm{C}$ for $60 \mathrm{~min}$. The spent liquor (aqueous phase) was separated from solid by vacuum filtration upon the completion of pretreatment. Afterward, if ethanol washing was needed, the solid fraction was washed by $700 \mathrm{~mL}$ warm ethanol solution $\left(65 \%(v / v), 50{ }^{\circ} \mathrm{C}\right)$ three times to dissolve the ethanol extractable lignin and followed by washing by $700 \mathrm{~mL}$ DI water four times to remove the residual ethanol. The cellulose-rich solid fraction was homogenized in a blender for $15 \mathrm{~s}$ and then used for fermentation and the aqueous phase was subject to detoxification. They were both stored at $4{ }^{\circ} \mathrm{C}$ until use.

The EOL was collected from the spent liquor and the ethanol washes. Threefold DI water was added to precipitate lignin and then the lignin fraction was separated by filtration and then washed thoroughly with DI water, dried in air and then in the oven $\left(105{ }^{\circ} \mathrm{C}\right)$. Sample from the mixture of filtrate and water washes was taken to determine the water-solubles. The collected materials include $39.0 \mathrm{~g}$ wood pulp, $14.2 \mathrm{~g}$ EOL and $14.2 \mathrm{~g}$ watersolubles after pretreatment of $80 \mathrm{~g}$ oven-dry wood. The water-solubles contained $9.50 \mathrm{~g}$ carbohydrates, $2.31 \mathrm{~g}$ acid-soluble lignin, $0.35 \mathrm{~g}$ HMF, $0.71 \mathrm{~g}$ furfural, and 1.37 g acetic acid.

\section{Chemical analysis of raw biomass and pretreated OPLP}

The extractives content in raw biomass, organosolv-pretreated OPLP-UW and OPLP-W (unwashed OPLP and washed OPLP) was determined as previously described [45]. The composition analysis of carbohydrate and lignin before and after ethanol organosolv pretreatment was carried out using extractives-free samples as previously described [46]. The sugar content of prehydrolysate was determined according to NREL standard method, NREL/TP-510-42623 [47]. The chemical composition of untreated and ethanol organosolv-pretreated loblolly pine is shown in Table 2.

\section{Enzymatic hydrolysis}

Cellic CTec 2 was used in enzymatic hydrolysis of pretreated biomass and its filter paper enzyme activity was $126 \mathrm{FPU} / \mathrm{mL}$. Enzymatic hydrolysis of OPLP-W and OPLP-UW (moisture content, 70\%) was carried out in $125-\mathrm{mL}$ serum bottle with a working volume of $50 \mathrm{~mL}$ with glucan loading of $5.8 \%(w / v)$. Two different conditions were performed with both OPLP-W and OPLPUW for SHF and SSF conditions, respectively: (1) $\mathrm{pH} 4.8$ controlled by $50 \mathrm{mM}$ citrate buffer, $50{ }^{\circ} \mathrm{C}$ and $150 \mathrm{rpm}$; (2) $\mathrm{pH} 6.0$ controlled by adding $0.25 \mathrm{~g} \mathrm{CaCO}_{3}, 35{ }^{\circ} \mathrm{C}$ and $80 \mathrm{rpm}$. To study the effect of lignin on enzymatic

Table 2 Chemical composition of untreated and ethanol organosolv-pretreated loblolly pine

\begin{tabular}{llll}
\hline & Untreated (\%) & \multicolumn{2}{l}{ Organosolv treated } \\
\cline { 3 - 4 } & & OPLP-UW (\%) & OPLP-W (\%) \\
\hline Glucan & $42.30 \pm 0.38$ & $72.74 \pm 0.20$ & $82.14 \pm 0.03$ \\
Xylan & $7.51 \pm 0.05$ & $2.17 \pm 0.01$ & $1.69 \pm 0.08$ \\
Galactan & $2.96 \pm 0.05$ & $0.36 \pm 0.03$ & $0.40 \pm 0.02$ \\
Arabinan & $1.78 \pm 0.03$ & $0.63 \pm .02$ & $0.69 \pm 0.05$ \\
Mannan & $11.17 \pm 0.08$ & $1.36 \pm 0.00$ & $0.99 \pm 0.02$ \\
Ethanol extractives & $1.18 \pm 0.05$ & $9.64 \pm 0.12$ & $0.79 \pm 0.04$ \\
Acid insoluble lignin & $29.45 \pm 0.27$ & $12.11 \pm 0.15$ & $13.52 \pm 0.10$ \\
$\quad$ AlL) & & & $0.35 \pm 0.01$ \\
Acid-soluble lignin (ASL) & $0.56 \pm 0.05$ & $0.28 \pm 0.00$ & $0.04 \pm 0.00$ \\
Ash & $0.36 \pm 0.02$ & $0.03 \pm 0.00$ & 0.04 \\
Total & 97.27 & 99.31 & 100.61 \\
\hline
\end{tabular}


hydrolysis, $0.3 \mathrm{~g}$ EOL (equivalent to the amount of lignin removed by washing) was added into the ethanol-washed substrate prior to enzymatic hydrolysis. The mixture was autoclaved at $121{ }^{\circ} \mathrm{C}$ for $15 \mathrm{~min}$, and then after cooling to room temperature, the enzyme was added to initiate the hydrolysis. Enzyme loading was $25 \mathrm{FPU} / \mathrm{g}$ glucan. Samples were taken aseptically to prevent contamination. The enzymatic hydrolysis yield was calculated as glucose released during hydrolysis divided by theoretical total glucose in the substrate.

\section{Separate hydrolysis and fermentation (SHF)}

For the SHF process, the mixture obtained from enzymatic hydrolysis (pH 4.8 controlled by $50 \mathrm{mM}$ citrate buffer, $50{ }^{\circ} \mathrm{C}$ and $150 \mathrm{rpm}$ ) was applied for fermentation. The volume of the mixture after enzymatic hydrolysis became $45 \mathrm{ml}$ due to the loss in the sample taken. It was brought to $50 \mathrm{~mL}$ after inoculation $(10 \% \mathrm{v} / \mathrm{v})$ and glucan loading became $5.2 \%(w / v)$. Upon completion of enzymatic hydrolysis, it was supplemented with previous filter-sterilized nutrients stock: $50 \mu \mathrm{L}$ vitamins ( $p$-aminobenzoic acid, $1 \mathrm{~g} / \mathrm{L}$, thiamine, $1 \mathrm{~g} / \mathrm{L}$, biotin, $0.01 \mathrm{~g} / \mathrm{L}$ ), $0.25 \mathrm{~mL}$ minerals $\left(\mathrm{MgSO}_{4} \cdot 7 \mathrm{H}_{2} \mathrm{O}, 40 \mathrm{~g} / \mathrm{L}, \mathrm{MnSO}_{4} \cdot \mathrm{H}_{2} \mathrm{O}\right.$, $\left.2 \mathrm{~g} / \mathrm{L}, \mathrm{FeSO}_{4} \cdot 7 \mathrm{H}_{2} \mathrm{O}, 2 \mathrm{~g} / \mathrm{L}, \mathrm{NaCl}, 2 \mathrm{~g} / \mathrm{L}\right)$ and $0.5 \mathrm{~mL}$ buffer $\left(\mathrm{K}_{2} \mathrm{HPO}_{4}, 50 \mathrm{~g} / \mathrm{L}, \mathrm{KH}_{2} \mathrm{PO}_{4}, 50 \mathrm{~g} / \mathrm{L}, \mathrm{CH}_{3} \mathrm{COONH}_{4}\right.$, $220 \mathrm{~g} / \mathrm{L}) \cdot \mathrm{CaCO}_{3}(0.25 \mathrm{~g})$ was added into the broth to control the $\mathrm{pH}$ during fermentation. Then the mixture in serum bottle was vacuumed and flushed with nitrogen for 7 cycles to remove oxygen by using a purge valve. The fermentation was initiated by adding $5 \mathrm{~mL}$ inoculum (10\% inoculation).

\section{Simultaneous saccharification and fermentation (SSF)}

The SSF process of both OPLP-W and OPLP-UW was carried out in $125-\mathrm{mL}$ serum bottle with working volume of $50 \mathrm{~mL}$ with glucan loading of $5.2 \%(w / v)$. They were autoclaved at $121{ }^{\circ} \mathrm{C}$ for $15 \mathrm{~min}$ and then supplemented with previous filter-sterilized nutrients stock the same as SHF process listed above. $\mathrm{CaCO}_{3}(0.25 \mathrm{~g})$ was added into the broth. Then the slurry in the serum bottle was vacuumed and flushed with nitrogen for 7 cycles to remove oxygen by using a purge valve. The enzyme loading was $25 \mathrm{FPU} / \mathrm{g}$ glucan and the enzyme was sterilized by passing through a $0.2-\mu \mathrm{m}$ membrane filter. The fermentation was initiated by adding enzyme and $5 \mathrm{~mL}$ inoculum $(10 \%$ inoculation). Both SHF and SSF were carried out at $35^{\circ} \mathrm{C}$ and $80 \mathrm{rpm}$.

SSF process supplemented with detoxified prehydrolysates Ethanol in prehydrolysate was evaporated at $40{ }^{\circ} \mathrm{C}$ in a rotary evaporator (IKA RV10 basic) and the $\mathrm{pH}$ was adjusted to 4.0 with $\mathrm{NaOH}$ before evaporation. The concentrated prehydrolysate was then diluted with DI water to make the total volume the same as that before evaporation. Two-step detoxification was carried out as described previously [43]. Briefly, the $\mathrm{pH}$ of prehydrolysate was adjusted to 10 by adding $\mathrm{Ca}(\mathrm{OH})_{2}$ and incubated at $90{ }^{\circ} \mathrm{C}$ and $100 \mathrm{rpm}$ for $30 \mathrm{~min}$. Afterward, $10 \mathrm{~g}$ activated Dowex 1X4 resin was added to $100 \mathrm{~mL}$ prehydrolysate and the whole mixture was incubated at $25{ }^{\circ} \mathrm{C}$ and $100 \mathrm{rpm}$ for $1 \mathrm{~h}$. The liquid was separated from the resin by centrifuge at $4000 \mathrm{rpm}$ for $10 \mathrm{~min}$ and then the $\mathrm{pH}$ was adjusted back to 7 with $\mathrm{H}_{2} \mathrm{SO}_{4}$. The detoxified prehydrolysate was supplemented into SSF in place of water.

All fermentations were performed in duplicates. Samples were taken periodically for sugar and $\mathrm{ABE}$ analysis. Butanol yield was calculated as butanol produced divided by glucose content in the pretreated substrate (and prehydrolysate if applicable) and is expressed as g/g. ABE yield was calculated as the total $\mathrm{ABE}$ produced divided by glucose content in the pretreated substrate (and prehydrolysate if applicable) and is expressed as g/g.

\section{Sugars and products analysis}

The sugar content was quantified by a Shimadzu (LC20A) HPLC system consisting of a degasser, autosampler, LC-20AD pump, and RID-10A detector, equipped with a $300 \mathrm{~mm} \times 7.8 \mathrm{~mm}$ i.d., $9 \mu \mathrm{m}$, Aminex HPX-87P column and a $30 \mathrm{~mm} \times 4.6 \mathrm{~mm}$ i.d. guard column of the same material (Bio-Rad, Hercules, CA). Nano-pure water was used as a mobile phase running at $0.6 \mathrm{~mL} / \mathrm{min}$. The column temperature was maintained at $85{ }^{\circ} \mathrm{C}$. Acetic acid, butyric acid, ethanol, acetone, butanol, HMF, and furfural were quantified by the same HPLC system (Shimadzu LC-20A) equipped with an Aminex HPX-87H column. The mobile phase was composed of $5 \mathrm{mM}$ of sulfuric acid running isocratic at $0.6 \mathrm{~mL} / \mathrm{min}$. The column temperature was kept at $45^{\circ} \mathrm{C}$.

\section{Abbreviations}

ABE: Acetone-butanol-ethanol; SHF: Separate hydrolysis and fermentation; SSF: Simultaneous saccharification and fermentation; OPLP: Organosolvpretreated loblolly pine; OPLP-UW: Organosolv-pretreated loblolly pineunwashed; OPLP-W: Organosolv-pretreated loblolly pine-washed; OPLP-W/ PH: Washed OPLP with detoxified prehydrolysates; EOL: Ethanol organosolv lignin; NREL: National Renewable Energy Lab.

\section{Acknowledgements}

We would like to acknowledge Prof. Yoon Y. Lee (Department of Chemical Engineering, Auburn University) and Prof. Sushil Adhikari (Department of Biosystems Engineering, Auburn University) for their contribution towards this article.

\section{Authors' contributions}

$J L$ and $Y Z$ designed and performed fermentations, analyzed samples, and wrote the manuscript; MT and SS joined in the discussion of experimental plans and edited the manuscript. All authors read and approved the final manuscript. 


\section{Funding}

The project is financially funded by the National Science Foundation (NSFCBET 1555633), University of Cincinnati, Office of the Vice President for Research-Collaborative Research Advancement Grants-Pilot Program, and URC Graduate Student Stipend and Research Cost Program. The project is also partially funded by the Innovative Research Team in Ministry of Education of China (IRT-17R1293).

\section{Availability of data and materials}

All data generated or analyzed during this study are included in this published article.

\section{Ethics approval and consent to participate}

Not applicable.

\section{Consent for publication}

Not applicable.

\section{Competing interests}

The authors declare that they have no competing interests.

\section{Author details}

${ }^{1}$ Alabama Center for Paper \& Bioresource Engineering, Auburn University, Auburn, AL 36849, USA. ${ }^{2}$ Engineering Laboratory for AgroBiomass Recycling \&Valorizing, College of Engineering, China Agricultural University, Beijing 100083, China. ${ }^{3}$ Department of Chemical and Environmental Engineering, University of Cincinnati, Cincinnati, $\mathrm{OH} 45221$, USA.

Received: 10 February 2020 Accepted: 2 April 2020 Published online: 10 April 2020

\section{References}

1. Ragauskas AJ, Williams CK, Davison BH, Britovsek G, Cairney J, Eckert CA Frederick WJ, Hallett JP, Leak DJ, Liotta CL, Mielenz JR, Murphy R, Templer $\mathrm{R}$, Tschaplinski T. The path forward for biofuels and biomaterials. Science. 2006;311(5760):484-9.

2. Stephanopoulos $G$. Challenges in engineering microbes for biofuels production. Science. 2007;315(5813):801-4.

3. Stocker M. Biofuels and biomass-to-liquid fuels in the biorefinery: catalytic conversion of lignocellulosic biomass using porous materials. Angew Chem Int Edit. 2008;47(48):9200-11.

4. Sklavounos $E$, lakovlev M, van Heiningen A. Study on conditioning of $\mathrm{SO}_{2}$-ethanol-water spent liquor from spruce chips/softwood biomass for ABE fermentation. Ind Eng Chem Res. 2013;52(11):4351-9.

5. Jones DT, Woods DR. Acetone-butanol fermentation revisited. Microbiol Rev. 1986;50(4):484-524.

6. Hüsemann MH, Papoutsakis ET. Solventogenesis in Clostridium acetobutylicum fermentations related to carboxylic acid and proton concentrations. Biotechnol Bioeng. 1988;32(7):843-52.

7. Bryant DL, Blaschek HP. Buffering as a means for increasing growth and butanol production by Clostridium acetobutylicum. J Ind Microbiol. 1988;3(1):49-55.

8. Maddox I, Steiner E, Hirsch S, Wessner S, Gutierrez N, Gapes J, Schuster K. The cause of "acid crash" and" acidogenic fermentations" during the batch acetone-butanol-ethanol (ABE-) fermentation process. J Mol Microbiol Biotechnol. 2000;2(1):95-100.

9. Ezeji T, Qureshi N, Blaschek H. Acetone butanol ethanol (ABE) production from concentrated substrate: reduction in substrate inhibition by fedbatch technique and product inhibition by gas stripping. Appl Microbiol Biotechnol. 2004;63(6):653-8.

10. Wang S, Zhang Y, Dong H, Mao S, Zhu Y, Wang R, Luan G, Li Y. Formic acid triggers the "acid crash" of acetone-butanol-ethanol fermentation by Clostridium acetobutylicum. Appl Environ Microbiol. 2011;77(5):1674-80.

11. Ramió-Pujol S, Ganigué R, Bañeras L, Colprim J. Incubation at 25 C prevents acid crash and enhances alcohol production in Clostridium carboxidivorans P7. Bioresour Technol. 2015;192:296-303.

12. Yang $X, T u M, X i e ~ R$, Adhikari S, Tong Z. A comparison of three $\mathrm{pH}$ control methods for revealing effects of undissociated butyric acid on specific butanol production rate in batch fermentation of Clostridium acetobutylicum. AMB Express. 2013;3(1):3.

13. Boonsombuti A, Komolpis K, Luengnaruemitchai A, Wongkasemjit S. Enhancement of $A B E$ fermentation through regulation of ammonium acetate and D-xylose uptake from acid-pretreated corncobs. Ann Microbiol. 2014;64(2):431-9.

14. Sasaki C, Kushiki Y, Asada C, Nakamura Y. Acetone-butanol-ethanol production by separate hydrolysis and fermentation (SHF) and simultaneous saccharification and fermentation (SSF) methods using acorns and wood chips of Quercus acutissima as a carbon source. Ind Crops Prod. 2014;62:286-92.

15. Qureshi N, Saha BC, Hector RE, Hughes SR, Cotta MA. Butanol production from wheat straw by simultaneous saccharification and fermentation using Clostridium beijerinckii: part I-batch fermentation. Biomass Bioenergy. 2008;32(2):168-75.

16. Raut MP, Couto N, Pham TK, Evans C, Noirel J, Wright PC. Quantitative proteomic analysis of the influence of lignin on biofuel production by Clostridium acetobutylicum ATCC 824. Biotechnol Biofuels. 2016;9(1):113.

17. Ibrahim MF, Abd-Aziz S, Yusoff MEM, Phang LY, Hassan MA. Simultaneous enzymatic saccharification and ABE fermentation using pretreated oil palm empty fruit bunch as substrate to produce butanol and hydrogen as biofuel. Renew Energy. 2015;77:447-55.

18. Linggang S, Phang LY, Wasoh H, Abd-Aziz S. Acetone-butanol-ethanol production by Clostridium acetobutylicum ATCC 824 using sago pith residues hydrolysate. BioEnergy Res. 2013;6(1):321-8.

19. Linggang S, Phang L, Wasoh M, Abd-Aziz S. Sago pith residue as an alternative cheap substrate for fermentable sugars production. Appl Biochem Biotechnol. 2012;167(1):122-31.

20. dos Santos AC, Ximenes E, Kim Y, Ladisch MR. Lignin-enzyme interactions in the hydrolysis of lignocellulosic biomass. Trends Biotechnol. 2019;37(5):518-31.

21. Li M, Pu Y, Ragauskas AJ. Current understanding of the correlation of lignin structure with biomass recalcitrance. Front Chem. 2016;4:45.

22. Lai C, Tu M, Li M, Yu S. Remarkable solvent and extractable lignin effects on enzymatic digestibility of organosolv pretreated hardwood. Bioresour Technol. 2014;156:92-9.

23. Li M, Si S, Hao B, Zha Y, Wan C, Hong S, Kang Y, Jia J, Zhang J, Li M. Mild alkali-pretreatment effectively extracts guaiacyl-rich lignin for high lignocellulose digestibility coupled with largely diminishing yeast fermentation inhibitors in Miscanthus. Bioresour Technol. 2014;169:447-54.

24. Deuss PJ, Scott M, Tran F, Westwood NJ, de Vries JG, Barta K. Aromatic monomers by in situ conversion of reactive intermediates in the acid-catalyzed depolymerization of lignin. J Am Chem Soc. 2015;137(23):7456-67.

25. Yao L, Chen C, Yoo CG, Meng X, Li M, Pu Y, Ragauskas AJ, Dong C, Yang $\mathrm{H}$. Insights of ethanol organosolv pretreatment on lignin properties of Broussonetia papyrifera. ACS Sustain Chem Eng. 2018;6(11):14767-73.

26. XuY, Li K, Zhang M. Lignin precipitation on the pulp fibers in the ethanolbased organosolv pulping. Colloids Surf A. 2007;301(1-3):255-63.

27. Huang Y, Sun S, Huang C, Yong Q, Elder T, Tu M. Stimulation and inhibition of enzymatic hydrolysis by organosolv lignins as determined by zeta potential and hydrophobicity. Biotechnol Biofuels. 2017;10(1):162.

28. Tu M, Pan X, Saddler JN. Adsorption of cellulase on cellulolytic enzyme lignin from lodgepole pine. J Agric Food Chem. 2009;57(17):7771-8.

29. Bhagia S, Wyman CE, Kumar R. Impacts of cellulase deactivation at the moving air-liquid interface on cellulose conversions at low enzyme loadings. Biotechnol Biofuels. 2019;12(1):1-15.

30. Georgieva TI, Hou X, Hilstrøm T, Ahring BK. Enzymatic hydrolysis and ethanol fermentation of high dry matter wet-exploded wheat straw at low enzyme loading. Biotechnology for fuels and chemicals. Berlin: Springer; 2007. p. 553-62.

31. Humbird D, Davis R, Tao L, Kinchin C, Hsu D, Aden A, Schoen P, Lukas J, Olthof B, Worley M. Process design and economics for biochemical conversion of lignocellulosic biomass to ethanol: dilute-acid pretreatment and enzymatic hydrolysis of corn stover. Golden: National Renewable Energy Lab. (NREL); 2011.

32. Tao L, Schell D, Davis R, Tan E, Elander R, Bratis A. NREL 2012 achievement of ethanol cost targets: biochemical ethanol fermentation via dilute-acid pretreatment and enzymatic hydrolysis of corn stover. Golden: National Renewable Energy Lab. (NREL); 2014. 
33. Arantes V, Saddler JN. Cellulose accessibility limits the effectiveness of minimum cellulase loading on the efficient hydrolysis of pretreated lignocellulosic substrates. Biotechnol Biofuels. 2011;4(1):3.

34. Kyriacou A, Neufeld RJ, MacKenzie CR. Effect of physical parameters on the adsorption characteristics of fractionated Trichoderma reesei cellulase components. Enzyme Microb Technol. 1988;10(11):675-81.

35. Bernardez TD, Lyford K, Hogsett DA, Lynd LR. Adsorption of Clostridium thermocellum cellulases onto pretreated mixed hardwood, Avicel, and lignin. Biotechnol Bioeng. 1993;42(7):899-907.

36. Lai C, Tu M, Yong Q, Yu S. Synergistic effects of $\mathrm{pH}$ and organosolv lignin addition on the enzymatic hydrolysis of organosolv-pretreated loblolly pine. RSC Adv. 2018;8(25):13835-41.

37. Mandels M, Hontz L, Nystrom J. Enzymatic hydrolysis of waste cellulose. Biotechnol Bioeng. 1974;16(11):1471-93.

38. Min BC, Ramarao BV. Mechanisms of the inhibition of enzymatic hydrolysis of waste pulp fibers by calcium carbonate and the influence of nonionic surfactant for mitigation. Bioprocess Biosyst Eng. 2017;40(6):799-806

39. Min BC, Bhayani B, Jampana $\vee$, Ramarao B. Enhancement of the enzymatic hydrolysis of fines from recycled paper mill waste rejects. Bioresour Bioprocess. 2015;2(1):40.

40. Lai C, Tu M, Shi Z, Zheng K, Olmos LG, Yu S. Contrasting effects of hardwood and softwood organosolv lignins on enzymatic hydrolysis of lignocellulose. Bioresour Technol. 2014;163:320-7.

41. Lu CC, Yu L, Varghese S, Yu MR, Yang ST. Enhanced robustness in acetonebutanol-ethanol fermentation with engineered Clostridium beijerinckil overexpressing adhE2 and ctfAB. Bioresour Technol. 2017;243:1000-8.
42. Ibrahim MF, Linggang S, Jenol MA, Yee PL, Abd-Aziz S. Effect of buffering system on acetone-butanol-ethanol fermentation by Clostridium acetobutylicum ATCC 824 using pretreated oil palm empty fruit bunch. BioResources. 2015;10(3):3890-907.

43. Li J, Shi S, Tu M, Via B, Sun FF, Adhikari S. Detoxification of organosolvpretreated pine prehydrolysates with anion resin and cysteine for butanol fermentation. Appl Biochem Biotechnol. 2018;186(3):662-80.

44. Xiao Z, Zhang X, Gregg DJ, Saddler JN. Effects of sugar inhibition on cellulases and $\beta$-glucosidase during enzymatic hydrolysis of softwood substrates. In: Proceedings of the twenty-fifth symposium on biotechnology for fuels and chemicals held May 4-7, 2003, in Breckenridge, CO, 2004. Berlin: Springer. p. 1115-26.

45. Sluiter A, Ruiz R, Scarlata C, Sluiter J, Templeton D. Determination of extractives in biomass. Laboratory Analytical Procedure (LAP). 2005. p. 1617.

46. Sluiter A, Hames B, Ruiz R, Scarlata C, Sluiter J, Templeton D, Crocker D. Determination of structural carbohydrates and lignin in biomass. Lab Anal Proced. 2008;1617:1-16.

47. Sluiter A, Hames B, Ruiz R, Scarlata C, Sluiter J, Templeton D. Determination of sugars, byproducts, and degradation products in liquid fraction process samples. Golden: National Renewable Energy Laboratory; 2006.

\section{Publisher's Note}

Springer Nature remains neutral with regard to jurisdictional claims in published maps and institutional affiliations.
Ready to submit your research? Choose BMC and benefit from:

- fast, convenient online submission

- thorough peer review by experienced researchers in your field

- rapid publication on acceptance

- support for research data, including large and complex data types

- gold Open Access which fosters wider collaboration and increased citations

- maximum visibility for your research: over $100 \mathrm{M}$ website views per year

At BMC, research is always in progress.

Learn more biomedcentral.com/submissions 